\title{
ine \\ Deoxynivalenol: Toxicology, Degradation by Bacteria, and Phylogenetic Analysis
}

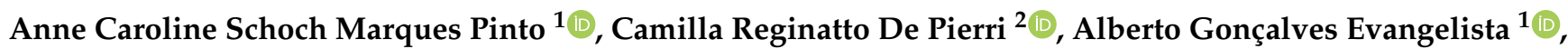 \\ Ana Silvia de Lara Pires Batista Gomes ${ }^{1}$ (1) and Fernando Bittencourt Luciano ${ }^{1, *}$
}

1 Graduate Program in Animal Science, School of Life Sciences, Pontifícia Universidade Católica do Paraná, 1155 Imaculada Conceição Street, Prado Velho, Curitiba 80215-901, Brazil; pinto.anne@pucpr.edu.br (A.C.S.M.P.); alberto.evangelista@pucpr.edu.br (A.G.E.); anaslpbg@gmail.com (A.S.d.L.P.B.G.)

2 Graduate Program in Sciences-Biochemistry, Department of Biochemistry and Molecular Biology, Federal University of Paraná, 100 Coronel Francisco H. dos Santos Avenue, Jardim das Américas, Curitiba 81530-000, Brazil; camillareginatto.p@gmail.com

* Correspondence: fernando.luciano@pucpr.br

check for updates

Citation: Pinto, A.C.S.M.; De Pierri, C.R.; Evangelista, A.G.; Gomes, A.S.d.L.P.B.; Luciano, F.B. Deoxynivalenol: Toxicology, Degradation by Bacteria, and Phylogenetic Analysis. Toxins 2022, 14, 90. https://doi.org/10.3390/ toxins 14020090

Received: 20 December 2021

Accepted: 20 January 2022

Published: 25 January 2022

Publisher's Note: MDPI stays neutral with regard to jurisdictional claims in published maps and institutional affiliations.

Copyright: (C) 2022 by the authors. Licensee MDPI, Basel, Switzerland. This article is an open access article distributed under the terms and conditions of the Creative Commons Attribution (CC BY) license (https:// creativecommons.org/licenses/by/ $4.0 /)$.

\begin{abstract}
Deoxynivalenol (DON) is a toxic secondary metabolite produced by fungi that contaminates many crops, mainly wheat, maize, and barley. It affects animal health, causing intestinal barrier impairment and immunostimulatory effect in low doses and emesis, reduction in feed conversion rate, and immunosuppression in high doses. As it is very hard to completely avoid DON's production in the field, mitigatory methods have been developed. Biodegradation has become a promising method as new microorganisms are studied and new enzymatic routes are described. Understanding the common root of bacteria with DON degradation capability and the relationship with their place of isolation may bring insights for more effective ways to find DON-degrading microorganisms. The purpose of this review is to bring an overview of the occurrence, regulation, metabolism, and toxicology of DON as addressed in recent publications focusing on animal production, as well as to explore the enzymatic routes described for DON's degradation by microorganisms and the phylogenetic relationship among them.
\end{abstract}

Keywords: biodegradation; deoxynivalenol; phylogeny; DON; mycotoxins

Key Contribution: Understanding the phylogenetic patterns of DON degraders is an important step to provide clues to optimize screening for new organisms with this potential. Additionally, this review brings a current overview of DON's negative effects in animal production.

\section{Introduction}

Mycotoxins are toxic secondary metabolites produced by fungi that infect crops and can be produced in the field, during postharvest procedures, and in storage. The main genera involved in mycotoxin production are Alternaria, Aspergillus, Cladosporium, Fusarium, and Penicillium [1]. Around 400 mycotoxins have been described so far, and they differ in their structure, metabolization, and level of toxicological effects [2]. However, they are mostly stable to thermal processes and have negative effects on human and animal health [3].

Up to $80 \%$ of the grains produced worldwide are contaminated with at least one mycotoxin, but cooccurrence of two or more mycotoxins is very common, increasing their risk to human and animal health [4].

Among the mycotoxins characterized, trichothecenes are a group of sesquiterpenoids produced by Fusarium sp. that comprises deoxynivalenol (DON) and its acetylated forms, nivalenol (NIV), T-2 toxin, and HT-2 toxin [5]. In recent years, research on DON's toxicology 
and mitigation methods has become more common because of DON's high incidence across the world.

In this review, we aimed to bring an overview of occurrence, regulation, metabolism, and toxicology of deoxynivalenol as discussed in recent publications and explore the enzymatic routes currently described for DON's degradation by microorganisms and the phylogenetic relationship among them, focusing on animal production. For this, we gathered studies that identified bacteria with the ability to transform DON into compounds that were less toxic than the parent toxin.

\section{Results and Discussion}

\subsection{Occurrence, Regulation, Ingestion, and Metabolism}

Grain contamination by mycotoxins may occur in the field or during storage, and factors such as temperature, high humidity, and handling are key points, as they can favor the production of mycotoxins [6].

DON is commonly found in temperate areas. Studies have reported that no DON has been identified in grains kept at water activity $\left(a_{w}\right)<0.9$ and temperatures lower than $11{ }^{\circ} \mathrm{C}$ [7]. Hope et al. [7] demonstrated that for both Fusarium graminearum and F. culmorum - main DON producers-ideal conditions for the toxin's production are $25^{\circ} \mathrm{C}$ and $\mathrm{a}_{\mathrm{w}}>$ 0.98 , which is in agreement with Ramirez and colleagues [8]. The use of fungicides can also stimulate DON's production, especially in low doses, as ineffective doses promote mild to medium levels of stress to the fungus [7]. Among the practices of crop handling-e.g., fungicide and fertilizer application-the use of Fusarium-resistant cultivars seems to have the greatest positive influence on maintaining low levels of DON in grains. These cultivars were developed to present different genes that promote resistance to Fusarium head blight, a common wheat disease associated with DON [9].

DON, also known as vomitoxin, is the most prevalent mycotoxin according to the last survey report from Biomin [10], a referenced company in the field of mycotoxins, which analyzed 21,709 maize and wheat samples from all continents of the world. The study indicated high prevalence of DON in China (mainland and Taiwan), Middle East and Central America, where $86 \%, 78 \%$, and $76 \%$ of the samples, respectively, were contaminated with the toxin. In South America, wheat samples presented an average of $\geq 1.5 \mu \mathrm{g} / \mathrm{g}$ of DON, representing a high risk for animal production, especially swine. In Oceania, this toxin was found in only $18 \%$ of samples. It is noteworthy that Oceania presented the lowest rate of all mycotoxins analyzed in this survey, and the risk for animal production was considered low to moderate. Higher concentrations of DON were observed in the 2020 survey than in the survey performed by Biomin in 2019, increasing the demand for more effective solutions for this issue.

Considering the panorama presented, regulations were established by governments enforcing maximum tolerable levels (MTL) of the toxin in foods and animal feed. Food intended for humans has its own regulation, which is more severe than that for animal feed, especially for foods destined for infants, who are more susceptible to the toxic effects of DON [11].

In 2004, the Food and Agriculture Organization (FAO) [12] released a worldwide survey on mycotoxin regulation status comparing the situations in 2003 and 1995. DON regulations were found in more countries after these nine years, although many of them considered these limits only for foods and not feed. In 2016, Romer Labs, a renowned company in the mycotoxin field, also released a survey showing that some countries are now regulating DON's presence in feed [13]. Taken together, these data show a tendency toward more severe regulations, expanding DON control to other crops besides maize and wheat.

Legislation varies widely among the regulatory agencies of different countries. The European Commission (EC) has established detailed legislation, applying lower limits to swine production $(0.9 \mu \mathrm{g} / \mathrm{mL})$ than the Food and Drug Administration (FDA) of the United States (FDA), which recommends $5 \mu \mathrm{g} / \mathrm{mL}$. South Africa and Canada established 
similar levels to those of the EC $(1 \mu \mathrm{g} / \mathrm{mL})$. Table 1 summarizes legislation established by the FDA [14]; the Canadian Food Inspection Agency [15]; the South African Department of Agriculture, Forestry, and Fisheries [16]; and the European Commission [17].

Table 1. Recommended levels of deoxynivalenol in animal feed established by regulatory public agencies worldwide.

\begin{tabular}{|c|c|c|c|}
\hline Agency & Specifications & Limit (mg/kg) & Reference \\
\hline \multirow{2}{*}{ FDA (United States) } & $\begin{array}{l}\text { Grains and grain by-products destined for ruminating } \\
\text { beef and feedlot cattle older than } 4 \text { months and for chicken }\end{array}$ & 10 & \multirow{2}{*}{ [14] } \\
\hline & $\begin{array}{l}\text { Grain and grain by-products destined for swine } \\
\text { and other animals }\end{array}$ & 5 & \\
\hline \multirow{4}{*}{ EFSA (EU) } & Cereals and cereal products except for maize by-products & 8 & \multirow{4}{*}{ [17] } \\
\hline & Maize by-products & 12 & \\
\hline & Complementary and complete feeding stuffs for animals & 5 & \\
\hline & Complementary and complete feeding stuffs for pigs & 0.9 & \\
\hline \multirow{2}{*}{$\begin{array}{l}\text { Food Inspection Agency } \\
\text { (Canada) }\end{array}$} & Diets for cattle and poultry & 5 & \multirow{2}{*}{ [15] } \\
\hline & Diets for swine, young calves, and lactating dairy animals & 1 & \\
\hline \multirow{6}{*}{$\begin{array}{l}\text { Department of Agriculture, } \\
\text { Forestry, and Fisheries } \\
\text { (South Africa) }\end{array}$} & Feeding stuffs on a full ration basis for: & & \multirow{6}{*}{ [16] } \\
\hline & Pigs & 1 & \\
\hline & Cattle & 5 & \\
\hline & Calves up to 4 months & 2 & \\
\hline & Dairy Cattle & 3 & \\
\hline & Poultry & 4 & \\
\hline
\end{tabular}

Some countries do not have official guidelines on MTL for animal feed. In Asia, each country makes its own regulations, and according to the Romer Labs report, China and Japan are the only countries that recommend MTL for DON in animal feed. Japan covers only specific groups, such as cows over 3 months of age [13]. Australia does not present specific regulations for this toxin in feed, probably because of the low levels found in the country and, therefore, the low incidence of mycotoxicosis in animals [18]. It is expected that in the coming years, with increased visibility of DON's effects on the food chain supported by consistent research, new regulations will be established.

Deoxynivalenol MTLs were set only on cereals because DON presents a low occurrence in other products. Cereals are the main entry point for this mycotoxin in daily food and feed, because grains are a staple worldwide, especially maize and wheat. Swine and broilers are heavily exposed to DON, as their diets are composed mainly by grains, compared to other production animals [19].

Toxin daily intake is hard to measure in animals because of the different nutrient requirements of each species and even during different growth phases within the same species. Furthermore, as many countries do not have specific legislation for animal feed, and several types of feed can be used in this process, it is even harder to obtain a general estimate of the situation. What is certain is that both humans and animals are constantly exposed to DON, as it is not possible to totally extinguish fungal contamination in crops such as wheat and corn and thereby avoid the production of this toxin.

Once it is ingested by an animal, DON metabolization occurs in the intestine. In this process, some metabolites such as DON-3S, DON-GlcA, and DOM-1 may be generated in broilers [20] and in swine. The high transformation of DON into DON-3S and rapid elimination of the parent toxin may be the reasons why poultry is less susceptible to the effects of the toxin [20]. A suggested route for DON metabolism in poultry is its absorption in jejunum, transformation to DON sulfate forms (DON-3-S and DON-15-S) in the intestine, and excretion through bile and urine [21]. 
Swine are more sensitive to DON because of their high rate of absorption of the toxin in the upper digestive system, especially in the small intestine. Urine was found as the main excretion route, with DON being the best biomarker in this matrix, indicating a lower rate of metabolization by pigs than by poultry [22]. Microbiota composition is also a key factor for this toxin's metabolization, as some microorganisms are capable of transforming the toxin into less toxic compounds, although this is not common in swine [23]. Fast tissue distribution was also observed, with $98 \%$ of metabolization occurring after 12 to $24 \mathrm{~h}$; only traces were identified after this period [24]. Figure 1 summarizes poultry's and swine's main DON metabolization routes by oral ingestion.

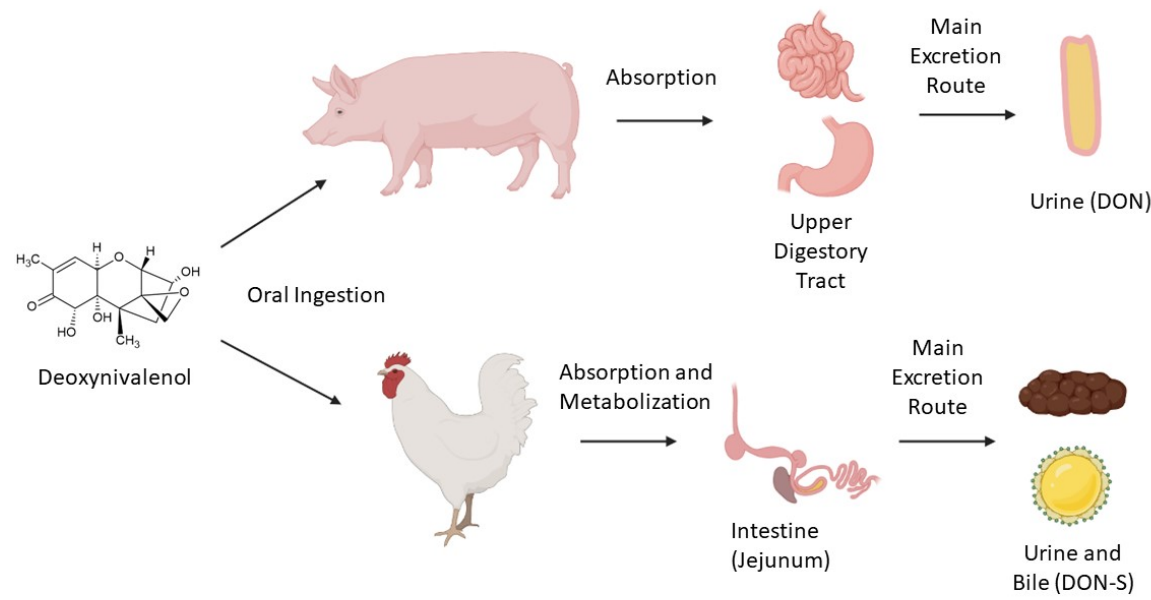

Figure 1. Main metabolization routes (simplified) of deoxynivalenol ingested orally by swine and poultry.

Lack of research and adequate regulations for mycotoxins are a risk to animal feed safety worldwide. Regarding DON, most research has focused on swine, followed by poultry, and the metabolism in these organisms is well documented. In ruminants, recent studies demonstrating the metabolism of vomitoxin are scarce. Ruminants are considered resistant because of their robust microbiota, which can transform the toxin into less toxic metabolites [25]. However, evidence has pointed to modulatory effects of mycotoxins on the intestinal microbiota of ruminants, which must be further investigated [26].

Soon, more severe control of DON is expected, as MTLs for this toxin tend to be included in countries where it is not regulated. It should also be more severely controlled than the existent regulations, especially as climate change can favor its production [27].

\subsection{DON's Mechanisms of Toxicity}

DON is classified as a sesquiterpenoid and possesses in its structure an epoxy group at C12-13 and hydroxyl groups at C3, C7, and C15, which are mainly responsible for its toxicity $[28,29]$.

Recent studies have shown a change in gene regulation as one effect of DON exposure, mainly affecting immune response genes, especially those linked to cytokines, which are signaling molecules that regulate the inflammatory response. There has also been evidence of disruption in the expression of genes related to nutrient transport, barrier function, cell cycle regulation, and mitochondrial function, leading to malfunction of the animal cell [30,31]. In high doses (e.g., $8 \mu \mathrm{g} / \mathrm{g}$ of feed), DON can suppress genes related to immune response [32]. DON has also presented upregulation of apoptotic gene expression, leading to cell death of hippocampal nerve cells in piglets [33].

At a molecular level, DON affects ribosomal activity by binding into the $60 \mathrm{~S}$ unit and inducing ribotoxic stress, leading to deficient protein synthesis. Changes in the mitochondrial structure and functioning were also observed. It also causes activation of mitogen-activated protein kinases (MAPK), leading to impairment of cell proliferation and apoptosis [33]. 
DON exerts its toxicity mainly in the gastrointestinal tract (GIT), and when in high doses, it provokes a reduction in goblet cell production. These cells are responsible for mucus production and help to maintain the integrity of the intestinal barrier. DON also affects the expression of tight junction proteins, such as claudins, that are responsible for regulating epithelial cell permeability and cell adhesion in the intestine [34]. This is especially worrying because the GIT enables adequate nutrient absorption, and this function may be impaired.

The intestinal barrier and a healthy microbiome also protect the animal against pathogens, and they are both negatively affected by DON [35]. Differences between the microbiota in the small intestines of weaning piglets fed with DON and those fed with a DON-free diet were reported [36]. Clear signals of dysbiosis, such as decrease in the population of Firmicutes-involved in the metabolism of nutrients and maintenance of intestinal health-and increased presence of Actinobacteria were noticed in piglets fed with DON. Similar results were found in weaning rabbits, with decreased microbiota diversity under the presence of high levels of DON [37].

Microbiota also play an important role in protecting the host from pathogen growth along with the immune system, which also suffers under the effects of DON. Changes in the T-cell differentiation pattern, decreasing the proliferation of cells that are directly involved in immune response, were found [38]. This result was supported by Cai and colleagues [39], who described a decrease in naïve cell differentiation into antibody-secreting cells due to lower cytokine receptor expression on the cell surface. Furthermore, they demonstrated that the toxin affected the immune response of mice infected with Listeria monocytogenes, intensifying the infection.

Alterations in the reproductive cycle have also been noticed in animals intoxicated with DON. The mycotoxin $(2 \mu \mathrm{g} / \mathrm{mL})$ has provoked disruption in the hormonal cycle, stimulating the release of progesterone and estrogens in vitro in porcine ovarian granulosa cells [40]. Disruption of the histological pattern and impairment of follicular development in ovarian explants of pigs were also demonstrated [41].

The toxin also restrained testicular development causing anomalies in its structure and impaired blood-testis barrier integrity in mice [42]. Sperm viability was also decreased, and morphology alteration of the gametes was found, results that were supported by Tassis et al. [43] in their study with boar semen and Yang et al. [44] in their study with BALB/c mice. One study also indicated that testicular function was not the only factor negatively affecting the male reproductive function and that neuroendocrine activity may suffer important alterations as an effect of DON [42]. Altered activity in the brains of piglets was suggested, especially in the release of neurotransmitters responsible for physiological and nervous system regulations, such as decreases in dopamine and GABA and increases in norepinephrine and 5-hydroxytryptamine [45]. One possible effect is the modulation of appetite.

The brain cell morphology of piglets was also altered by DON, with a lack of organelle and vacuole formation when challenged with $2.2 \mu \mathrm{g} / \mathrm{g}$ of the toxin added to the feed. DON also decreased the antioxidant activity in the brain because of a reduction in superoxide dismutase and glutathione peroxidase activity [45]. Furthermore, an increase in bloodbrain barrier permeability and a decrease in cell viability were found in in vitro models as well as in rats, chickens, pigs, and mice. All together, these studies point to brain activity disorders and homeostasis imbalance [46].

Other studies have reported that other organs, namely the liver [47], kidney, and spleen [48], are also affected by DON. This results in immunosuppression, metabolic alterations, and disturbance in the amino acid production profile, leading to malfunction of physiological processes. Figure 2 summarizes the effects of DON on targeted animal organs and systems. 


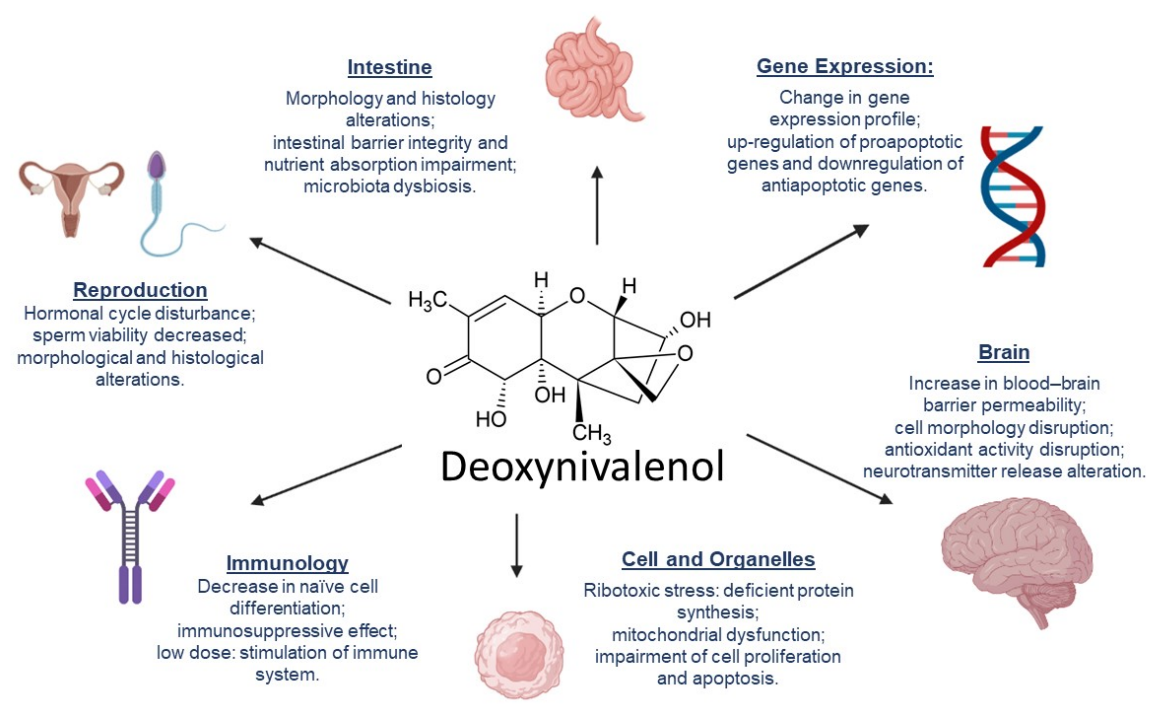

Figure 2. Effects of deoxynivalenol in animal organs and systems.

DON's toxicity in vivo is well documented. Negative impacts were reported in grass carp [49], broilers [50,51], piglets [36,52], finishing pigs [53], mice [54,55], and rabbits [56]. Among food animals, a predominance of studies involved pigs and piglets rather than broilers, probably because of the higher tolerance to the toxin presented by broilers. Important factors to be considered for the severity of the toxin's effect are dose and time of exposure, which determine the outcome of the intoxication. Serviento and colleagues [53] compared three treatment groups of finishing pigs fed with $3 \mu \mathrm{g} / \mathrm{g}$ of DON. The first group was exposed to the toxin once a day from 113 to $119 \mathrm{~d}$ of life; the second group was exposed to DON once a day from 134 to $140 \mathrm{~d}$; and the third group was exposed to the toxin in both periods. The results suggested that pigs' tolerance to DON's presence increased in the second exposure after 4 weeks, probably because of adaptations of their microbiota. They also showed that previous contact with the toxin did not avoid adverse effects of later exposures. However, it improved animal recovery from a second exposure to contaminated feed. In addition, it was observed that older animals exposed to the toxin presented lower average daily feed intake and daily weight gain than those challenged in early periods, indicating that age is also an important parameter to be considered.

Studies have shown immunosuppression in animals subjected to high doses of the toxin $[29,37,38,56]$. However, a recent study showed that low doses of DON can stimulate the immune system, increasing lymphocyte and goblet cell numbers and activating signaling pathways with an increased production of cytokines, suggesting a dose-dependent effect in the immune response [57]. Alassane-Kpembi et al. [58] pointed out that commonly used detection methods may fail to identify the potential harms from low-exposure doses of DON and that omics have the potential to provide specific fingerprints about the mycotoxin's effects.

The masked forms of DON also represent a threat to food security, and they are often neglected. Acetyl and glycosylated modifications are among the most common masked forms, and some of them may be more toxic than DON itself. Studies have shown faster absorption of acetylated forms and toxic effects, such as activation of the MAPK signaling pathway, similar to those of DON. In addition, digestive enzymes and microorganisms can transform 15-A-DON and 3-A-DON in DON [59].

Because of the diverse toxic effects of the toxin in different systems of the animal organism, some strategies have been developed to mitigate them. Biodegradation is a potential mechanism to decrease DON's toxicity and has been widely studied in recent years. The most reported biodegradation metabolites are DOM-1 and 3-epi-DON, which were found to be less toxic than the parent toxin $[60,61]$. Their characteristic lower toxicity was confirmed by Bracarense and colleagues [52] in vivo using piglets fed with $3 \mu \mathrm{g} / \mathrm{g}$ 
of DON, DOM-1, and 3-epi-DON. Results demonstrated histological modifications and proinflammatory response in the intestines, livers, and lymph nodes of animals treated with DON. However, those treated with DOM-1 and 3-epi-DON presented similar scores as those in the control group.

Reduction in T-cell proliferation and disruption to the expression of molecules involved in immune response were observed in vitro when cells were exposed to $1.6 \mu \mathrm{M}$ of DON, yet a 10-fold higher dose of DOM-1 did not exert any of these effects [62]. Mayer and colleagues [63], working with five different cell lines-mice macrophages (RAW 264.7), porcine intestinal cells (IPEC-1 and IPEC-J2), trout gill (RTgill-W1), and human liver cell (HepG2)—found similar results.

Toxic effects of DON are well documented, especially in swine, which has been found the most sensitive species to DON in animal production. Although many in vitro studies have reported a sharp drop in toxicity via microbial transformation, generating DOM-1 and 3-epi-DON, there is a lack of studies of in vivo toxicity, especially about 3-epi-DON, which was described in the literature later than DOM-1.

In vivo analyses often require special evaluation and authorization from the ethics committee on the use of animals, an additional step that is often bureaucratic and time consuming, although necessary. Further in vivo studies are required to fully confirm the lower toxicity of these metabolites, as systemic effects cannot be fully evaluated in in vitro studies.

\subsection{Biodegradation of Deoxynivalenol}

Biodegradation is a process that consists of the degradation of one compound into another mediated by living organisms, such as bacteria, yeast, or fungi. In the mycotoxin context, it is interesting that the subproducts generated in this process are less toxic than the parent toxin and may not negatively affect either animal or plant cells.

For some mycotoxins, such as aflatoxin B1, the most common approach for mitigation in animal production is to include feed additives such as binders, which can reach $90+\%$ adsorption of the toxin in the GIT of livestock animals [64]. However, DON has a low affinity to binders in general due to its structural low polarity. An in vitro study showed that bentonite clays, cellulose products, yeast cell wall products, and activated charcoal products had adsorption rates of $3.24 \%, 11.6 \%, 22.9 \%$, and $14.4 \%$ of DON, respectively, which are not effective results when applied in animal feed [64]. Therefore, development products containing microorganisms with the ability to degrade DON into less toxic compounds represent an interesting strategy. Few works have discussed fungi and yeast such as Aspergillus tubingensis [65], Aspergillus oryzae and Rhizopus oryzae [66], and Saccharomyces pastorianus [67] as DON degraders. Most studies have isolated bacteria from different genera presenting a variety of degradation pathways. The first report of a DON-degrading microorganism was made by King and colleagues [68] in rumen fluid, with DOM-1 as a subproduct and no identification of the species involved in this process. The first organism to be described as a DON detoxifier was part of the Agrobacterium-Rhizobium group and called strain E3-39 [69]. Since then, many other species have described (Table 2), and other degradation subproducts, such as 3-keto-DON [59], 3-epi-DON [70], and 3-epi-DOM-1 [71], have been identified. 
Table 2. Microorganisms described as deoxynivalenol degraders in vitro, their sources of isolation, the metabolites formed, and the conditions used in the relevant studies.

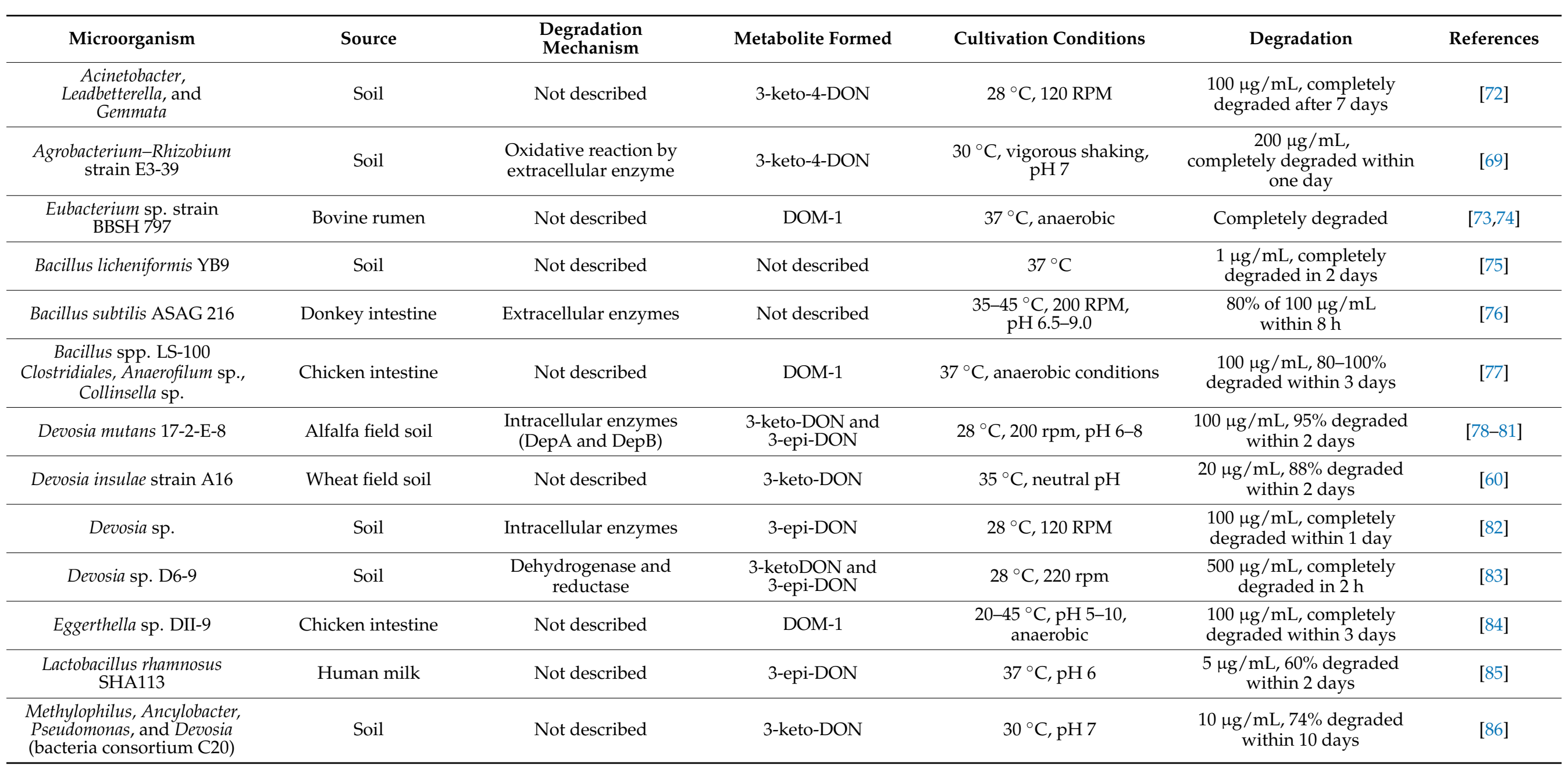


Table 2. Cont.

\begin{tabular}{|c|c|c|c|c|c|c|}
\hline Microorganism & Source & $\begin{array}{l}\text { Degradation } \\
\text { Mechanism }\end{array}$ & Metabolite Formed & Cultivation Conditions & Degradation & References \\
\hline $\begin{array}{l}\text { Nocardioides sp. strain } \\
\text { WSN05-2 }\end{array}$ & Wheat field soil & Not described & 3-epi-DON & $28^{\circ} \mathrm{C}$, agitation & $\begin{array}{c}1000 \mu \mathrm{g} / \mathrm{mL} \text {, completely } \\
\text { degraded after } 10 \text { days }\end{array}$ & {$[70]$} \\
\hline Nocardioides sp. NSM2 & Wheat leaves and soil & Not described & 3-epi-DON & $28^{\circ} \mathrm{C}, 120 \mathrm{RPM}$ & $\begin{array}{l}100 \mu \mathrm{g} / \mathrm{mL}, \text { completely } \\
\text { degraded within } 1 \text { day }\end{array}$ & [82] \\
\hline Nocardioides sp. ZHH-013 & Soil & Living cells & $\begin{array}{l}\text { 3-keto-DON and } \\
\text { 3-epi-DON }\end{array}$ & $30^{\circ} \mathrm{C}, 220 \mathrm{RPM}$ & $\begin{array}{c}33.747 \mathrm{mM}, 80 \% \text { degraded } \\
\text { within } 24 \mathrm{~h}\end{array}$ & [87] \\
\hline $\begin{array}{c}\text { Paradevosia shaoguanensis } \\
\text { DDB001 }\end{array}$ & Wheat soil & Not described & 3-epi-DON & $30^{\circ} \mathrm{C}, 220 \mathrm{RPM}$ & $\begin{array}{c}200 \mu \mathrm{g} / \mathrm{mL}, \text { completely } \\
\text { degraded in } 3 \text { days }\end{array}$ & [88] \\
\hline $\begin{array}{l}\text { Pelagibacterium halotolerans } \\
\text { ANSP101 }\end{array}$ & Seawater & Intracellular protein & 3-keto-DON & $28^{\circ} \mathrm{C}$ & $\begin{array}{c}50 \mu \mathrm{g} / \mathrm{mL}, 80 \% \text { degraded } \\
\text { after } 12 \mathrm{~h}\end{array}$ & [89] \\
\hline $\begin{array}{l}\text { Pseudomonas, Clostridium, } \\
\text { and Desulfitobacterium } \\
\text { (bacterial consortium PGC3) }\end{array}$ & Wheat field soil & Not described & DOM-1 & $20-37^{\circ} \mathrm{C}, \mathrm{pH}$ 5-10 & $\begin{array}{c}100 \mu \mathrm{g} / \mathrm{mL} \text {, completely } \\
\text { degraded after } 7 \text { days }\end{array}$ & $\begin{array}{l}{[90]} \\
{[91]}\end{array}$ \\
\hline $\begin{array}{c}\text { Pseudomonas sp. Y1 and } \\
\text { Lysobacter sp. S1 (bacteria } \\
\text { consortium LZ-N1) }\end{array}$ & Soil samples & Enzymatic epimerization & 3-epi-DON & $30^{\circ} \mathrm{C}$, agitation & $\begin{array}{c}50 \mu \mathrm{g} / \mathrm{mL} \text {, completely } \\
\text { degraded within } 2 \text { days }\end{array}$ & [92] \\
\hline $\begin{array}{c}\text { Serratia, Clostridium, } \\
\text { Citrobacter, } \\
\text { Enterococcus, } \\
\text { Stenotrophomonas, } \\
\text { Streptomyces, and } \\
\text { Citrobacter freundii A47 }\end{array}$ & Soil & Not described & DOM-1 & $\begin{array}{l}12-40{ }^{\circ} \mathrm{C}, \mathrm{pH} \text { 6.0-7.5, } \\
\text { aerobic and anaerobic }\end{array}$ & $\begin{array}{c}50 \mu \mathrm{g} / \mathrm{mL}, 99 \% \text { degraded } \\
\text { within } 60 \mathrm{~h}\end{array}$ & [93] \\
\hline Sphingomonas S3-4 & Wheat fields & $\begin{array}{l}\text { Oxidation mediated by } \\
\text { aldo/keto reductase }\end{array}$ & $\begin{array}{l}\text { 3-keto-DON and } \\
\text { 3-epi-DON }\end{array}$ & $28^{\circ} \mathrm{C}, 220 \mathrm{RPM}$ & $\begin{array}{c}100 \mu \mathrm{g} / \mathrm{mL} \text {, completely } \\
\text { degraded in } 3 \text { days }\end{array}$ & [94] \\
\hline $\begin{array}{l}\text { Sphingomonas sp. strain } \\
\text { KSM1 }\end{array}$ & Lake water & P450 enzymes & 16-hydroxy-DON & $37^{\circ} \mathrm{C}$ & $\begin{array}{l}300 \mu \mathrm{g} / \mathrm{mL} \text {, completely } \\
\text { degraded in } 3 \text { days }\end{array}$ & [95] \\
\hline Slackia sp. D-G6 & Chicken intestines & Not described & DOM-1 & $\begin{array}{c}32-47^{\circ} \mathrm{C}, \mathrm{pH} \text { 6-10, } \\
\text { anaerobic }\end{array}$ & $\begin{array}{c}25 \mu \mathrm{g} / \mathrm{mL} \text {, completely } \\
\text { degraded in } 1 \text { day }\end{array}$ & [96] \\
\hline $\begin{array}{l}\text { Stenotrophomonas and Blautia } \\
\text { (microbial consortium } \\
\text { DX100) }\end{array}$ & Soil samples & $\begin{array}{l}\text { De-epoxidation by } \\
\text { intracellular reductases }\end{array}$ & DOM-1 & $20-40{ }^{\circ} \mathrm{C}, \mathrm{pH} 6-7.5$ & $\begin{array}{c}50 \mu \mathrm{g} / \mathrm{mL}, 100 \% \text { degraded } \\
\text { in } 2 \text { days }\end{array}$ & [97] \\
\hline
\end{tabular}


The first reports were made in anaerobic conditions, because ruminants showed less susceptibility to DON toxicity than monogastric animals [98]. Therefore, it was plausible to assume that rumen bacteria played an important role in DON metabolization. Many other sources were used to collect potential degrading microorganisms, including fish [99] and chicken intestine [77], environmental samples from water [89], soil [72], and plants [82]. In the last 10 years, sampling from soil or plants in aerobic conditions has become more common for screening because of the observation that although toxins are frequently found in grains, they are not found in the soil where these plants are cultivated.

Many researchers have used the media enrichment method, which involves adding the toxin into culture media and proceeding with several subcultures, aiming to find potential DON degraders $[69,75,81]$. This technique favors the microorganisms that metabolize DON, especially when it is used as a single carbon source. In this case, DON degraders become predominant in the sample and can be easily isolated [97]. It is also possible, although less common, to test this ability with single species already isolated. This technique consists of cultivation of the microorganism in the presence of the toxin and evaluation of its degradation rate [100].

\subsection{Enzymatic Pathways}

Understanding the enzymatic pathways through which DON biodegradation occurs is crucial for the development of products containing microorganisms with such ability. Cofactors of the enzymatic reactions must be considered and identified as well [101]. Studies have shown different routes for enzymatic degradation of the toxin, mainly deepoxidation and epimerization, including- extra and intracellular enzymes and aerobic and anaerobic pathways.

The de-epoxidation reaction of vomitoxin involves the removal of an oxygen atom and incorporation of three hydrogen atoms, forming DOM-1 [102]. Epimerization takes place when the $-\mathrm{OH}$ radical in the $\mathrm{C} 3$ carbon is epimerized through an isomerization reaction, forming 3-epi-DON [78]. Both reactions are demonstrated in Figure 3. The two metabolites generated in de-epoxidation and epimerization reactions of DON were well described in in vitro studies and were found to be less toxic than the parent toxin.
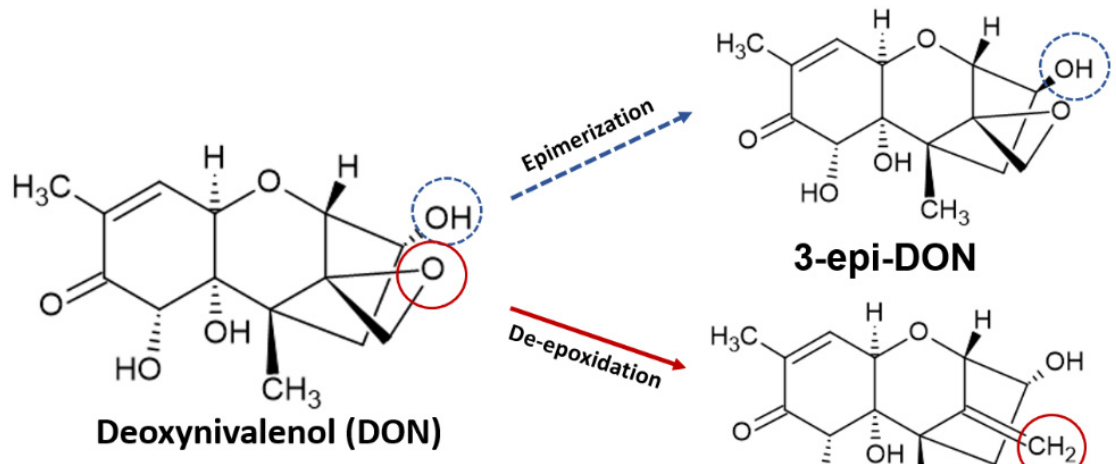

3-epi-DON
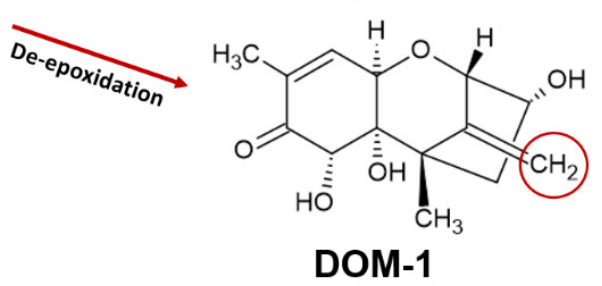

Figure 3. Epimerization and de-epoxidation of deoxynivalenol, producing 3-epi-deoxynivalenol (3-epi-DON) and deepoxydeoxynivalenol (DOM-1), respectively.

Degradation of DON by intracellular enzymes was described by Zhang et al. [89]. In this study, the cell lysate of Pelagibacterium halotolerans, isolated from sea water, showed the strongest DON-degrading ability $(72.5 \%$ of $500 \mu \mathrm{g} / \mathrm{mL})$ under 30 to $40{ }^{\circ} \mathrm{C}$ and pH 8 to 10 . Acid $\mathrm{pH}$ (lower than 6) and heat $\left(100{ }^{\circ} \mathrm{C}\right.$ for $\left.10 \mathrm{~min}\right)$ greatly decreased the degradation of the mycotoxin, leading to the conclusion that this degradation was mediated by $\mathrm{pH}-$ dependent enzymes. 
Jia and colleagues [76] isolated the supernatant of Bacillus subtilis ASAG 216 grown in Luria-Bertani broth, which was subsequently incubated with $100 \mu \mathrm{g} / \mathrm{mL}$ of DON. A degradation rate of $81.8 \%$ was found at $35-50{ }^{\circ} \mathrm{C}$ and $\mathrm{pH}$ 6.5-9. Heat, sodium dodecyl sulfate, and proteinase $\mathrm{K}$ treatments significantly reduced DON's degradation, which indicated that extracellular enzymes were part of this process.

Aerobic and anaerobic conditions also play an important role on DON's epimerization by microorganisms [93]. A microbial consortium was isolated from agricultural soil with the capacity to totally degrade $50 \mu \mathrm{g} / \mathrm{mL}$ of DON at $27^{\circ} \mathrm{C}$ in nutrient broth and mineral media enriched with $0.5 \%(w / v)$ peptone. In this case, aerobic degradation $(60 \mathrm{~h})$ was faster than anaerobic degradation $(96 \mathrm{~h})$, which may be explained by the composition of the consortium involving mostly aerobic or facultative anaerobic organisms. He et al. [78] also demonstrated a relationship among oxygen presence, population increase, and DON degradation in which aerobiosis increased cell proliferation and DON degradation.

In anaerobic cultivation, full transformation of DON to DOM-1 was achieved at $37^{\circ} \mathrm{C}$ using a consortium of Bacillus spp., Clostridiales, Anaerofilum sp., and Collinsella sp. originated from chicken intestine [77]. Anaerobic conditions were also used in Eubacterium cultivation with the formation of the same subproduct, DOM-1 [73].

No study performing experiments in anaerobic conditions was found in which 3-epiDON was formed as a by-product. Bacteria capable of degrading DON into 3-epi-DON were mainly from environmental sources such as wheat, soil, and water, so the production of this metabolite may be conditioned to the species that are prevalent in these environments. Furthermore, 3-epi-DON was reported in more studies than DOM-1, probably because of the aerobic sources used. Production of DOM-1 seems to be prevalent in anaerobic environments such as the intestine and rumen, since only a few studies have reported DOM-1 production under aerobic conditions.

Hassan et al. [103] worked with cell lysates of Devosia mutans in aerobic conditions and described a two-step epimerization of DON involving the oxidation of DON to 3-keto-DON and a reduction to 3-epi-DON with NADPH as an enzymatic cofactor. They also showed that the enzymes involved in the two reactions were physically separated. He et al. [83], also working with Devosia strain D6-9, found the same degradation pattern.

A hydroxylation reaction was reported, when DON was metabolized by Sphingomonas sp. strain KSM1, involving three enzymes and NADH [95]. In this reaction, DON was transformed into 16-hydroxy-deoxynivalenol through a bacterial p450 catalytical system, which is related to the metabolism of toxins [104]. This system was also efficient against NIV and 3-ADON. This genus was also described as a DON degrader in a two-step reaction that generated 3-oxo-DON as intermediate and 3-epi-DON as the final product [94]. The strain used in this study, named SE-4, was isolated from wheat fields and was able to completely degrade the toxin in mineral media supplemented with $50 \mu \mathrm{g} / \mathrm{mL}$ at $28^{\circ} \mathrm{C}$.

Different degradation pathways between Gram-positive and Gram-negative bacteria were reported, as only Gram-positive bacteria were able to use DON as a carbon source, and they needed preincubation with the toxin to fully express this ability [82]. Both categories were able to form 3-epi-DON as an intermediate, so there are probably similarities in the degradation process performed by these bacteria, but further studies are necessary to clarify the degradation mechanisms suggested [82].

In recent years, continuous effort from many research groups has been dedicated to fully understanding the biodegradation mechanisms of deoxynivalenol and the role of each microorganism or enzyme in this process. Pioneer studies reported only on the degradation itself and subproducts, but recent work elucidated the entire enzymatic pathways, their cofactors, and optimal conditions for occurrence, such as temperature, $\mathrm{pH}$, and oxygen presence or absence. However, complete studies are still scarce. The next steps may include expanding in-depth work to species already described as DON degraders to fully understand their degradation pathways. Then, another important issue to be figured out is how to deliver these active microorganisms, either in animal feed or in plant 
fields, as these environments may affect the microorganisms' metabolism and, therefore, vomitoxin degradation.

\subsection{Phylogenetic Analyses}

Phylogenetic relationships provide an overview of evolutionary patterns between genes and species through phylogenetic trees, offering a structure to biological variation or traits.

We selected studies that provided microorganism identification and sample source and described which DON metabolite was produced in the biodegradation process (listed in Table 2). Studies that did not fit into these criteria were not considered when building the tree.

The 16S rDNA gene is highly conserved among prokaryotes, not susceptible to horizontal exchange of genes, and the most used in bacterial taxonomic classification [105]. In this review, we used the $16 \mathrm{~S}$ rDNA sequence provided by the authors of the articles gathered here to build a phylogenetic tree (Table S1), and similarities in DON metabolite production, particularly that of DOM-1, 3-keto-4-DON and 3-epi-DON, were sought. The $16 \mathrm{~S}$ gene itself does not provide a means to assess the presence or activity of other genes involved in the production of these metabolites. Even so, some patterns were identified in the $16 S$ phylogeny.

The rRNA16S gene sequences of the strains were aligned using Clustal Omega [106] with default parameters. The inference of the maximum likelihood (ML) phylogenetic tree and the Bootstrap calculation were performed using the IQ-TREE software [107] using the ModelFinder method [108] for 1000 replicates. The tree figure (Figure 4) was organized using Adobe Illustrator CC 2017 software (version 21.0.0). In order to provide an overview of the evolutionary relationship of these organisms against a larger dataset, we also constructed a phylogenetic tree (Figure S1) using 205 16s rRNA (cited in the phylogenetic studies available in Table S2). Coherent distribution of these organisms was also observed.

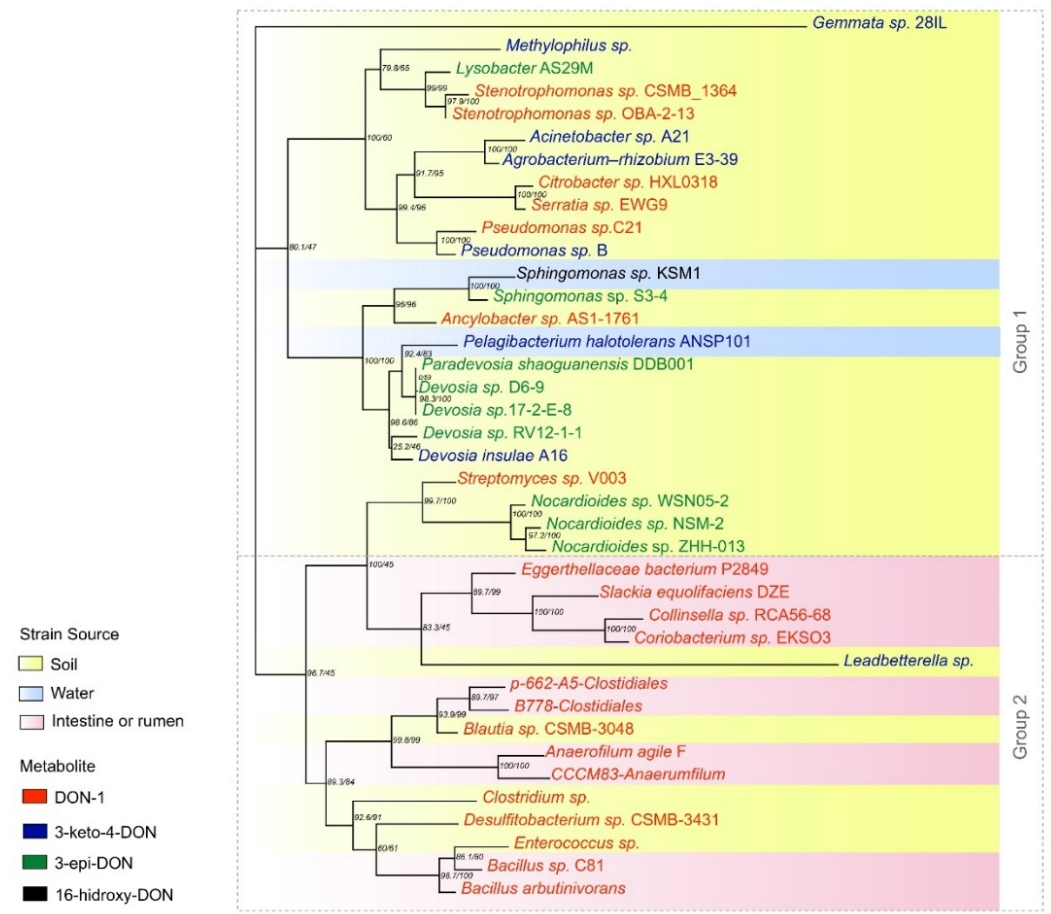

Figure 4. Phylogeny of $16 \mathrm{~S}$ rRNA genes from organisms isolated from environmental or gastrointestinal sources that produce DOM-1, 3-keto-4-DON and 3-epi-DON metabolites. 
Thirty-nine sequences fitting the criteria mentioned above were available. From these microorganisms, $32.5 \%$ were cultivated in anaerobiosis and $23 \%$ were also cultivated in aerobiosis. This information should be taken in account to define the application of these organisms, since agricultural practices involve aerobic environments. For animal application, these organisms may be used as feed supplements, as the GI tract is mostly anaerobic or microaerophilic.

Another important parameter to be considered for the final use of these organisms is the environmental $\mathrm{pH}$ where they would be applied. Studies tested $\mathrm{pH}$ levels ranging from 5 to 10 and observed the ability of microorganisms to degrade the toxin in these different $\mathrm{pHs}$, not the survival of the microorganism. To be applied in animal systems, the microorganism must survive the acid $\mathrm{pH}$ of the stomach, but not necessarily keep their degradation activity in this $\mathrm{pH}$, considering that the $\mathrm{pH}$ of the intestine is close to neutral. The intestine is the place where DON is mostly absorbed, especially in swine. Most studies gathered here used neutral pH (7.0). Eight articles used slightly acid pH (6.0), and another eight used alkaline $\mathrm{pH}$ (7.5 to 10$)$.

Besides $\mathrm{pH}$ and atmospheric conditions, other facts must be considered, such as the microorganism's capacity to proliferate and its ability to resist industrial processes such as drying or concentration. Bioprocessing itself may also involve some issues that decrease cell viability, e.g., shear stress [109]. The formation of spores may be an interesting characteristic to look for once it increases the microorganism's resistance to thermal processes. From the studies gathered here, only two spore-forming organisms were reported, namely Bacillus licheniformis YB9 [75] and Bacillus subtilis ASAG 216 [76]. However, spore formation is not mandatory, as the only product approved for animal use with the ability to mitigate trichothecenes' effects contains Eubacterium BBSH 797, a non-spore forming organism. Its recommended final dose is $1.7 \times 10^{8} \mathrm{CFU} / \mathrm{kg}$ of feedstuff [110].

The main source of DON-degrading organisms described was either soil or plants, which together accounted for $70 \%$ of the isolated sequences (27). The rumen and intestine provided ten microorganisms able to degrade the toxin (25\%). Only two strains were originated from water $(5 \%)$, and one of these strains was also the only one registered to produce 16-hydroxy-deoxynivalenol. This indicates that soil and plants are most favorable sources to perform screening tests for DON-degrading microorganisms.

According to the distribution of branches on the tree, the formation of two distinct groups was observed: group 1, with mixed characteristics, with strains from different sources producing all three types of metabolites, but mainly 3-keto-DON and 3-epi-DON; and group 2, composed by strains from the intestine/rumen or soil producing DOM-1. The uncultured Leadbetterella sp. strain was not included in this group because of the low bootstrap. It is interesting to mention that those bacteria isolated from soil included in group 2, such as Enterococcus and Blautia, are commonly found in the intestine/rumen, showing a pattern of source/metabolite.

A random distribution was observed in group 1 regarding both source and metabolite produced. This can be explained by the multiple mechanisms described in the articles. Although only a few manuscripts described full metabolic pathways, including enzymes and cofactors involved in the process, some features - such as the active source of degradation (e.g., supernatant, cell lysate, or living cell) - demonstrated differences in the degradation process, indicating different evolutive pathways.

Strains capable of producing 3-epi-DON as a DON metabolite were all soil-borne (Nocardioides sp. ZHH-013, Nocardioides sp. NSM-2, Nocardioides sp. WSN05-2, Devosia sp. 17-2-E -8, Devosia sp. RV12-1-1 and Pseudomonas sp. B). The same pattern was observed in strains that produced 3-keto-DON (uncultured Leadbetterella sp., Devosia insulae A16, Agrobacterium E3-39, Acinetobacter sp. A21, uncultured Methylophilus, and Gemmata sp. 28IL). Some articles reported 3-keto-DON as an intermediate in the enzymatic reaction leading to the formation of 3-epi-DON, which explains the similar pattern [86,102].

On the other hand, the origin of the strains that produce DOM- 1 is variable. However, it was noted that $100 \%$ of the gut/rumen samples were composed of strains that produced 
this metabolite (Bacillus sp. C81, Anaerophilum agile F, Coriobacterium sp. EKSO3_Collinsella, and Collinsella sp. RCA56-68).

From the 21 articles gathered to build the tree, six reported production of DOM-1, five 3-keto-DON, and nine 3-epi-DON as the final metabolite of the DON degradation process. Because of the different cell lines used and methodologies applied in toxicology studies, it is not clear which of these three metabolites is least toxic. What is well known is that they are less toxic than DON itself. Therefore, biodegradation processes that form any of these by-products are useful to mitigate toxic effects [111].

\section{Conclusions}

Deoxynivalenol is proven to have different but deleterious toxic effects in both low and high doses in animal systems. Biodegradation is a very interesting approach to mitigate DON's toxicity, even though most studies that isolated DON-degrading microorganisms still lacked in-depth descriptions of the metabolic pathways and the effects of the microorganism in vivo in food animals. Many genera were reported as DON degraders, ranging from several evolutive paths. A common root was observed between microorganisms that produced DOM-1 and their intestinal origin. Soil was the most common source used to find microorganisms with the ability to convert DON into less toxic compounds, and 3-epi-DON was the usual metabolite produced. Now, the physiology of theses microorganisms must be taken in account to develop effective products to mitigate the effects of this toxin in livestock production.

Supplementary Materials: The following supporting information can be downloaded at: https: / / www.mdpi.com/article/10.3390/toxins14020090/s1, Table S1. The 16S rRNA gene sequences of DON-degrading bacteria provided in each study, Table S2. The $16 \mathrm{~S}$ rRNA gene sequences of DONdegrading bacteria and other bacteria used in each phylogenetic study provided in the articles, Figure S1: The 16S rRNA genes from 205 organisms listed in Table S2. Highlighted (red) are the 40 organisms shown in Figure 1 and Table S1. References [112-115] are cited in the supplementary materials.

Author Contributions: Conceptualization, A.C.S.M.P. and F.B.L.; methodology, C.R.D.P.; formal analysis, C.R.D.P. and A.S.d.L.P.B.G.; data curation, A.C.S.M.P.; writing-original draft preparation, A.C.S.M.P.; writing-review and editing, A.S.d.L.P.B.G., A.G.E., C.R.D.P. and F.B.L.; supervision, F.B.L.; project administration, F.B.L.; funding acquisition, F.B.L. All authors have read and agreed to the published version of the manuscript.

Funding: This study was supported by the Brazilian National Council for Scientific and Technological Development, processes CNPq 308598/2020-2, 142196/2019-3 and 437728/2018-8; the Coordination for the Improvement of Higher Education Personnel, process CAPES 001; and the Pontifical Catholic University of Parana.

Institutional Review Board Statement: Not applicable.

Informed Consent Statement: Not applicable.

Data Availability Statement: The data presented in this review paper are openly available in published papers listed in References.

Conflicts of Interest: The authors declare no conflict of interest.

\section{References}

1. Holanda, D.M.; Kim, S.W. Mycotoxin Occurrence, Toxicity, and Detoxifying Agents in Pig Production with an Emphasis on Deoxynivalenol. Toxins 2021, 13, 171. [CrossRef] [PubMed]

2. Cinar, A.; Onbaş1, E. Mycotoxins: The Hidden Danger in Foods. In Mycotoxins and Food Safety; IntechOpen: London, UK, 2020.

3. Bullerman, L.B.; Bianchini, A. Stability of mycotoxins during food processing. Int. J. Food Microbiol. 2007, 119, 140-146. [CrossRef] [PubMed]

4. Eskola, M.; Kos, G.; Elliott, C.T.; Hajšlová, J.; Mayar, S.; Krska, R. Worldwide contamination of food-crops with mycotoxins: Validity of the widely cited 'FAO estimate' of 25\%. Crit. Rev. Food Sci. Nutr. 2020, 60, 2773-2789. [CrossRef] [PubMed]

5. Cope, R.B. Trichothecenes. In Veterinary Toxicology; Elsevier: Amsterdam, The Netherlands, 2018; pp. $1043-1053$. 
6. Pallez-Barthel, M.; Cocco, E.; Vogelgsang, S.; Beyer, M. Frequency of Deoxynivalenol Concentrations above the Maximum Limit in Raw Winter Wheat Grain during a 12-Year Multi-Site Survey. Agronomy 2021, 11, 960. [CrossRef]

7. Hope, R.; Aldred, D.; Magan, N. Comparison of environmental profiles for growth and deoxynivalenol production by Fusarium culmorum and F. graminearum on wheat grain. Lett. Appl. Microbiol. 2005, 40, 295-300. [CrossRef]

8. Ramirez, M.L.; Chulze, S.; Magan, N. Temperature and water activity effects on growth and temporal deoxynivalenol production by two Argentinean strains of Fusarium graminearum on irradiated wheat grain. Int. J. Food Microbiol. 2006, 106, $291-296$. [CrossRef]

9. Beyer, M.; Klix, M.B.; Klink, H.; Verreet, J.-A. Quantifying the effects of previous crop, tillage, cultivar and triazole fungicides on the deoxynivalenol content of wheat grain-A review. J. Plant Dis. Prot. 2006, 113, 241-246. [CrossRef]

10. Biomin Pesquisa Mundial de Micotoxinas: Impacto em 2021. Available online: https://www.biomin.net/br/science-hub/ pesquisa-mundial-de-micotoxinas-impacto-em-2021/ (accessed on 30 September 2021).

11. Herrera, M.; Bervis, N.; Carramiñana, J.J.; Juan, T.; Herrera, A.; Ariño, A.; Lorán, S. Occurrence and Exposure Assessment of Aflatoxins and Deoxynivalenol in Cereal-Based Baby Foods for Infants. Toxins 2019, 11, 150. [CrossRef]

12. FAO Worldwide Regulations for Mycotoxins in Food and Feed in 2003. Available online: http://www.fao.org/3/y5499e/y549 9e00.htm (accessed on 27 September 2021).

13. Romer Labs Worldwide Mycotoxin Regulations. Available online: https://www.romerlabs.com/en/knowledge-center/ knowledge-library/articles/news/worldwide-mycotoxin-regulations/ (accessed on 27 September 2021).

14. FDA Advisory Levels for Deoxynivalenol (DON) in Finished Wheat Products for Human Consumption and Grains and Grain By-Products Used for Animal Feed. Available online: https://www.fda.gov/regulatory-information/search-fda-guidancedocuments / guidance-industry-and-fda-advisory-levels-deoxynivalenol-don-finished-wheat-products-human (accessed on 6 October 2021).

15. Canadian Food Inspection Agency RG-8 Regulatory Guidance: Contaminants in Feed. Available online: https://inspection. canada.ca/animal-health/livestock-feeds/regulatory-guidance/rg-8/eng/1347383943203/1347384015909?chap=1 (accessed on 2 October 2021)

16. Department of Agriculture, Forestry and Fisheries of South Africa. Farm Feeds Regulations: Amendment Government Notices No. R. 70 of 12 February 2010. Available online: https:/ /www.gov.za/sites/default/files/gcis_document/201409/3293570.pdf (accessed on 2 October 2021).

17. Ec Recomendação Da Comissão 2006/576 de 17 de Agosto de 2006 Sobre a Presença de Desoxinivalenol, Zearalenona, Ocratoxina A, Toxinas T-2 e HT-2 e Fumonisinas em Produtos Destinados à Alimentação Animal. Available online: https: / / eur-lex.europa. eu/legal-content/EN/TXT/?uri=CELEX\%3A32006H0576 (accessed on 7 October 2021).

18. DAF Mould, Poisons and Other Toxins. Available online: https://www.daf.qld.gov.au/business-priorities/agriculture/animals/ pigs/health-diseases/mould-poisons-toxins (accessed on 6 October 2021).

19. Magnoli, A.P.; Poloni, V.L.; Cavaglieri, L. Impact of mycotoxin contamination in the animal feed industry. Curr. Opin. Food Sci. 2019, 29, 99-108. [CrossRef]

20. Riahi, I.; Ramos, A.J.; Pérez-Vendrell, A.M.; Marquis, V. A toxicokinetic study reflecting the absorption, distribution, metabolism and excretion of deoxynivalenol in broiler chickens. J. Appl. Anim. Res. 2021, 49, 284-288. [CrossRef]

21. Paulick, M.; Winkler, J.; Kersten, S.; Schatzmayr, D.; Schwartz-Zimmermann, H.; Dänicke, S. Studies on the Bioavailability of Deoxynivalenol (DON) and DON Sulfonate (DONS) 1, 2, and 3 in Pigs Fed with Sodium Sulfite-Treated DON-Contaminated Maize. Toxins 2015, 7, 4622-4644. [CrossRef] [PubMed]

22. Lauwers, M.; Croubels, S.; Letor, B.; Gougoulias, C.; Devreese, M. Biomarkers for Exposure as A Tool for Efficacy Testing of A Mycotoxin Detoxifier in Broiler Chickens and Pigs. Toxins 2019, 11, 187. [CrossRef] [PubMed]

23. Debevere, S.; Cools, A.; De Baere, S.; Haesaert, G.; Rychlik, M.; Croubels, S.; Fievez, V. In Vitro Rumen Simulations Show a Reduced Disappearance of Deoxynivalenol, Nivalenol and Enniatin B at Conditions of Rumen Acidosis and Lower Microbial Activity. Toxins 2020, 12, 101. [CrossRef] [PubMed]

24. Schelstraete, W.; Devreese, M.; Croubels, S. Comparative toxicokinetics of Fusarium mycotoxins in pigs and humans. Food Chem. Toxicol. 2020, 137, 111140. [CrossRef]

25. Guerre, P. Mycotoxin and Gut Microbiota Interactions. Toxins 2020, 12, 769. [CrossRef]

26. Korosteleva, S.N.; Smith, T.K.; Boermans, H.J. Effects of Feedborne Fusarium Mycotoxins on the Performance, Metabolism, and Immunity of Dairy Cows. J. Dairy Sci. 2007, 90, 3867-3873. [CrossRef]

27. van der Fels-Klerx, H.J.; Olesen, J.E.; Madsen, M.S.; Goedhart, P.W. Climate change increases deoxynivalenol contamination of wheat in north-western Europe. Food Addit. Contam. Part A 2012, 29, 1593-1604. [CrossRef]

28. Sundstøl Eriksen, G.; Pettersson, H.; Lundh, T. Comparative cytotoxicity of deoxynivalenol, nivalenol, their acetylated derivatives and de-epoxy metabolites. Food Chem. Toxicol. 2004, 42, 619-624. [CrossRef]

29. Sobrova, P.; Adam, V.; Vasatkova, A.; Beklova, M.; Zeman, L.; Kizek, R. Deoxynivalenol and its toxicity. Interdiscip. Toxicol. 2010, 3 , 94-99. [CrossRef]

30. Pierron, A.; Mimoun, S.; Murate, L.S.; Loiseau, N.; Lippi, Y.; Bracarense, A.-P.F.L.; Schatzmayr, G.; He, J.W.; Zhou, T.; Moll, W.-D.; et al. Microbial biotransformation of DON: Molecular basis for reduced toxicity. Sci. Rep. 2016, 6, 29105. [CrossRef] 
31. Reddy, K.E.; Lee, W.; Jeong, J.Y.; Lee, Y.; Lee, H.-J.; Kim, M.S.; Kim, D.-W.; Yu, D.; Cho, A.; Oh, Y.K.; et al. Effects of deoxynivalenoland zearalenone-contaminated feed on the gene expression profiles in the kidneys of piglets. Asian-Australas. J. Anim. Sci. 2018, 31, 138-148. [CrossRef] [PubMed]

32. Liao, P.; Liao, M.; Li, L.; Tan, B.; Yin, Y. Effect of deoxynivalenol on apoptosis, barrier function, and expression levels of genes involved in nutrient transport, mitochondrial biogenesis and function in IPEC-J2 cells. Toxicol. Res. 2017, 6, 866-877. [CrossRef] [PubMed]

33. Wang, X.; Fan, M.; Chu, X.; Zhang, Y.; Rahman, S.; Jiang, Y.; Chen, X.; Zhu, D.; Feng, S.; Li, Y.; et al. Deoxynivalenol induces toxicity and apoptosis in piglet hippocampal nerve cells via the MAPK signaling pathway. Toxicon 2018, 155, 1-8. [CrossRef] [PubMed]

34. Bracarense, A.-P.F.L.; Lucioli, J.; Grenier, B.; Drociunas Pacheco, G.; Moll, W.-D.; Schatzmayr, G.; Oswald, I.P. Chronic ingestion of deoxynivalenol and fumonisin, alone or in interaction, induces morphological and immunological changes in the intestine of piglets. Br. J. Nutr. 2012, 107, 1776-1786. [CrossRef]

35. Zhou, H.; Guog, T.; Dai, H.; Yu, Y.; Zhang, Y.; Ma, L. Deoxynivalenol: Toxicological profiles and perspective views for future research. World Mycotoxin J. 2020, 13, 179-188. [CrossRef]

36. Liu, M.; Zhang, L.; Chu, X.-H.; Ma, R.; Wang, Y.-W.; Liu, Q.; Zhang, N.-Y.; Karrow, N.A.; Sun, L.-H. Effects of deoxynivalenol on the porcine growth performance and intestinal microbiota and potential remediation by a modified HSCAS binder. Food Chem. Toxicol. 2020, 141, 111373. [CrossRef]

37. Wang, C.; Huang, L.; Wang, P.; Liu, Q.; Wang, J. The Effects of Deoxynivalenol on the Ultrastructure of the Sacculus Rotundus and Vermiform Appendix, as Well as the Intestinal Microbiota of Weaned Rabbits. Toxins 2020, 12, 569. [CrossRef]

38. Vatzia, E.; Pierron, A.; Hoog, A.M.; Saalmüller, A.; Mayer, E.; Gerner, W. Deoxynivalenol Has the Capacity to Increase Transcription Factor Expression and Cytokine Production in Porcine T Cells. Front. Immunol. 2020, 11, 2009. [CrossRef]

39. Cai, G.; Xia, S.; Zhong, F.; Liu, S.; Gu, J.; Yuan, Y.; Zhu, G.; Zou, H.; Liu, Z.; Bian, J. Zearalenone and deoxynivalenol reduced Th1mediated cellular immune response after Listeria monocytogenes infection by inhibiting CD4+ T cell activation and differentiation. Environ. Pollut. 2021, 284, 117514. [CrossRef]

40. Kolesarova, A.; Medvedova, M.; Halenar, M.; Sirotkin, A.V.; Bulla, J. The influence of deoxynivalenol and zearalenone on steroid hormone production by porcine ovarian granulosa cells in vitro. J. Environ. Sci. Health Part B 2017, 52, 823-832. [CrossRef]

41. Gerez, J.R.; Desto, S.S.; Bracarense, A.P.F.R.L. Deoxynivalenol induces toxic effects in the ovaries of pigs: An ex vivo approach. Theriogenology 2017, 90, 94-100. [CrossRef] [PubMed]

42. Cao, Z.; Huang, W.; Sun, Y.; Li, Y. Deoxynivalenol induced spermatogenesis disorder by blood-testis barrier disruption associated with testosterone deficiency and inflammation in mice. Environ. Pollut. 2020, 264, 114748. [CrossRef] [PubMed]

43. Tassis, P.D.; Tsakmakidis, I.A.; Nagl, V.; Reisinger, N.; Tzika, E.; Gruber-Dorninger, C.; Michos, I.; Mittas, N.; Basioura, A.; Schatzmayr, D. Individual and Combined In Vitro Effects of Deoxynivalenol and Zearalenone on Boar Semen. Toxins 2020, 12, 495. [CrossRef] [PubMed]

44. Yang, J.; Wang, J.; Guo, W.; Ling, A.; Luo, A.; Liu, D.; Yang, X.; Zhao, Z. Toxic Effects and Possible Mechanisms of Deoxynivalenol Exposure on Sperm and Testicular Damage in BALB/c Mice. J. Agric. Food Chem. 2019, 67, 2289-2295. [CrossRef]

45. Wang, X.; Chen, X.; Cao, L.; Zhu, L.; Zhang, Y.; Chu, X.; Zhu, D.; Rahman, S.; Peng, C.; Feng, S.; et al. Mechanism of deoxynivalenol-induced neurotoxicity in weaned piglets is linked to lipid peroxidation, dampened neurotransmitter levels, and interference with calcium signaling. Ecotoxicol. Environ. Saf. 2020, 194, 110382. [CrossRef]

46. Zhang, J.; You, L.; Wu, W.; Wang, X.; Chrienova, Z.; Nepovimova, E.; Wu, Q.; Kuca, K. The neurotoxicity of trichothecenes T-2 toxin and deoxynivalenol (DON): Current status and future perspectives. Food Chem. Toxicol. 2020, 145, 111676. [CrossRef]

47. Bracarense, A.P.F.L.; Basso, K.M.; Da Silva, E.O.; Payros, D.; Oswald, I.P. Deoxynivalenol in the liver and lymphoid organs of rats: Effects of dose and duration on immunohistological changes. World Mycotoxin J. 2017, 10, 89-96. [CrossRef]

48. Ji, J.; Zhu, P.; Cui, F.; Pi, F.; Zhang, Y.; Sun, X. The disorder metabolic profiling in kidney and spleen of mice induced by mycotoxins deoxynivalenol through gas chromatography mass spectrometry. Chemosphere 2017, 180, 267-274. [CrossRef]

49. Huang, C.; Feng, L.; Liu, X.-A.; Jiang, W.-D.; Wu, P.; Liu, Y.; Jiang, J.; Kuang, S.-Y.; Tang, L.; Zhou, X.-Q. The toxic effects and potential mechanisms of deoxynivalenol on the structural integrity of fish gill: Oxidative damage, apoptosis and tight junctions disruption. Toxicon 2020, 174, 32-42. [CrossRef]

50. de Souza, M.; Baptista, A.A.S.; Valdiviezo, M.J.J.; Justino, L.; Menck-Costa, M.F.; Ferraz, C.R.; da Gloria, E.M.; Verri, W.A.; Bracarense, A.P.F.R.L. Lactobacillus spp. reduces morphological changes and oxidative stress induced by deoxynivalenol on the intestine and liver of broilers. Toxicon 2020, 185, 203-212. [CrossRef]

51. Wu, S.; Liu, Y.; Duan, Y.; Wang, F.; Guo, F.; Yan, F.; Yang, X.; Yang, X. Intestinal toxicity of deoxynivalenol is limited by supplementation with Lactobacillus plantarum JM113 and consequentially altered gut microbiota in broiler chickens. J. Anim. Sci. Biotechnol. 2018, 9, 74. [CrossRef] [PubMed]

52. Bracarense, A.P.F.L.; Pierron, A.; Pinton, P.; Gerez, J.R.; Schatzmayr, G.; Moll, W.-D.; Zhou, T.; Oswald, I.P. Reduced toxicity of 3-epi-deoxynivalenol and de-epoxy-deoxynivalenol through deoxynivalenol bacterial biotransformation: In vivo analysis in piglets. Food Chem. Toxicol. 2020, 140, 111241. [CrossRef] [PubMed]

53. Serviento, A.M.; Brossard, L.; Renaudeau, D. An acute challenge with a deoxynivalenol-contaminated diet has short- and long-term effects on performance and feeding behavior in finishing pigs. J. Anim. Sci. 2018, 96, 5209-5221. [CrossRef] [PubMed] 
54. Rajput, S.A.; Shaukat, A.; Rajput, I.R.; Kamboh, A.A.; Iqbal, Z.; Saeed, M.; Akhtar, R.W.; Shah, S.A.H.; Raza, M.A.; El Askary, A.; et al. Ginsenoside Rb1 prevents deoxynivalenol-induced immune injury via alleviating oxidative stress and apoptosis in mice. Ecotoxicol. Environ. Saf. 2021, 220, 112333. [CrossRef]

55. Wang, L.; Wang, Y.; Shao, H.; Luo, X.; Wang, R.; Li, Y.; Li, Y.; Luo, Y.; Zhang, D.; Chen, Z. In vivo toxicity assessment of deoxynivalenol-contaminated wheat after ozone degradation. Food Addit. Contam. Part A 2017, 34, 103-112. [CrossRef]

56. Yang, W.; Huang, L.; Wang, P.; Wu, Z.; Li, F.; Wang, C. The Effect of Low and High Dose Deoxynivalenol on Intestinal Morphology, Distribution, and Expression of Inflammatory Cytokines of Weaning Rabbits. Toxins 2019, 11, 473. [CrossRef]

57. Liu, D.; Wang, Q.; He, W.; Chen, X.; Wei, Z.; Huang, K. Two-way immune effects of deoxynivalenol in weaned piglets and porcine alveolar macrophages: Due mainly to its exposure dosage. Chemosphere 2020, 249, 126464. [CrossRef]

58. Alassane-Kpembi, I.; Canlet, C.; Tremblay-Franco, M.; Jourdan, F.; Chalzaviel, M.; Pinton, P.; Cossalter, A.M.; Achard, C.; Castex, M.; Combes, S.; et al. 1H-NMR metabolomics response to a realistic diet contamination with the mycotoxin deoxynivalenol: Effect of probiotics supplementation. Food Chem. Toxicol. 2020, 138, 111222. [CrossRef]

59. Guo, H.; Ji, J.; Wang, J.; Sun, X. Deoxynivalenol: Masked forms, fate during food processing, and potential biological remedies. Compr. Rev. Food Sci. Food Saf. 2020, 19, 895-926. [CrossRef]

60. Wang, G.; Wang, Y.; Ji, F.; Xu, L.; Yu, M.; Shi, J.; Xu, J. Biodegradation of deoxynivalenol and its derivatives by Devosia insulae A16. Food Chem. 2019, 276, 436-442. [CrossRef]

61. He, J.W.; Bondy, G.S.; Zhou, T.; Caldwell, D.; Boland, G.J.; Scott, P.M. Toxicology of 3-epi-deoxynivalenol, a deoxynivalenoltransformation product by Devosia mutans 17-2-E-8. Food Chem. Toxicol. 2015, 84, 250-259. [CrossRef] [PubMed]

62. Vatzia, E.; Pierron, A.; Saalmüller, A.; Mayer, E.; Gerner, W. Deoxynivalenol Affects Proliferation and Expression of ActivationRelated Molecules in Major Porcine T-Cell Subsets. Toxins 2019, 11, 644. [CrossRef] [PubMed]

63. Mayer, E.; Novak, B.; Springler, A.; Schwartz-Zimmermann, H.E.; Nagl, V.; Reisinger, N.; Hessenberger, S.; Schatzmayr, G. Effects of deoxynivalenol (DON) and its microbial biotransformation product deepoxy-deoxynivalenol (DOM-1) on a trout, pig, mouse, and human cell line. Mycotoxin Res. 2017, 33, 297-308. [CrossRef] [PubMed]

64. Kong, C.; Shin, S.Y.; Kim, B.G. Evaluation of mycotoxin sequestering agents for aflatoxin and deoxynivalenol: An in vitro approach. Springerplus 2014, 3, 1-4. [CrossRef] [PubMed]

65. He, C.; Fan, Y.; Liu, G.; Zhang, H. Isolation and Identification of a Strain of Aspergillus Tubingensis With Deoxynivalenol Biotransformation Capability. Int. J. Mol. Sci. 2008, 9, 2366-2375. [CrossRef] [PubMed]

66. Garda-Buffon, J.; Kupski, L.; Badiale-Furlong, E. Deoxynivalenol (DON) degradation and peroxidase enzyme activity in submerged fermentation. Ciência e Tecnol. Aliment. 2011, 31, 198-203. [CrossRef]

67. Nathanail, A.V.; Gibson, B.; Han, L.; Peltonen, K.; Ollilainen, V.; Jestoi, M.; Laitila, A. The lager yeast Saccharomyces pastorianus removes and transforms Fusarium trichothecene mycotoxins during fermentation of brewer's wort. Food Chem. 2016, 203, 448-455. [CrossRef]

68. King, R.R.; McQueen, R.E.; Levesque, D.; Greenhalgh, R. Transformation of Deoxynivalenol (Vomitoxin) by Rumen Microorganisms. J. Agric. Food Chem. 1984, 32, 1181-1183. [CrossRef]

69. Shima, J.; Takase, S.; Takahashi, Y.; Iwai, Y.; Fujimoto, H.; Yamazaki, M.; Ochi, K. Novel detoxification of the trichothecene mycotoxin deoxynivalenol by a soil bacterium isolated by enrichment culture. Appl. Environ. Microbiol. 1997, 63, 3825-3830. [CrossRef]

70. Ikunaga, Y.; Sato, I.; Grond, S.; Numaziri, N.; Yoshida, S.; Yamaya, H.; Hiradate, S.; Hasegawa, M.; Toshima, H.; Koitabashi, M.; et al. Nocardioides sp. strain WSN05-2, isolated from a wheat field, degrades deoxynivalenol, producing the novel intermediate 3-epi-deoxynivalenol. Appl. Microbiol. Biotechnol. 2011, 89, 419-427. [CrossRef]

71. Vanhoutte, I.; De Mets, L.; De Boevre, M.; Uka, V.; Di Mavungu, J.; De Saeger, S.; De Gelder, L.; Audenaert, K. Microbial Detoxification of Deoxynivalenol (DON), Assessed via a Lemna minor L. Bioassay, through Biotransformation to 3-epi-DON and 3-epi-DOM-1. Toxins 2017, 9, 63. [CrossRef] [PubMed]

72. Wilson, N.; McMaster, N.; Gantulga, D.; Soyars, C.; McCormick, S.; Knott, K.; Senger, R.; Schmale, D. Modification of the Mycotoxin Deoxynivalenol Using Microorganisms Isolated from Environmental Samples. Toxins 2017, 9, 141. [CrossRef] [PubMed]

73. Fuchs, E.; Binder, E.M.; Heidler, D.; Krska, R. Structural characterization of metabolites after the microbial degradation of type A trichothecenes by the bacterial strain BBSH 797. Food Addit. Contam. 2002, 19, 379-386. [CrossRef]

74. He, P.; Young, L.G.; Forsberg, C. Microbial transformation of deoxynivalenol (vomitoxin). Appl. Environ. Microbiol. 1992, 58, 3857-3863. [CrossRef]

75. Wang, S.; Hou, Q.; Guo, Q.; Zhang, J.; Sun, Y.; Wei, H.; Shen, L. Isolation and Characterization of a Deoxynivalenol-Degrading Bacterium Bacillus licheniformis YB9 with the Capability of Modulating Intestinal Microbial Flora of Mice. Toxins 2020, 12, 184. [CrossRef] [PubMed]

76. Jia, R.; Cao, L.; Liu, W.; Shen, Z. Detoxification of deoxynivalenol by Bacillus subtilis ASAG 216 and characterization the degradation process. Eur. Food Res. Technol. 2021, 247, 67-76. [CrossRef]

77. Yu, H.; Zhou, T.; Gong, J.; Young, C.; Su, X.; Li, X.-Z.; Zhu, H.; Tsao, R.; Yang, R. Isolation of deoxynivalenol-transforming bacteria from the chicken intestines using the approach of PCR-DGGE guided microbial selection. BMC Microbiol. 2010, 10, 182. [CrossRef] [PubMed] 
78. He, J.W.; Hassan, Y.I.; Perilla, N.; Li, X.-Z.; Boland, G.J.; Zhou, T. Bacterial Epimerization as a Route for Deoxynivalenol Detoxification: The Influence of Growth and Environmental Conditions. Front. Microbiol. 2016, 7, 572. [CrossRef]

79. He, J. Microbial Strategies for Management of Fusarium graminearum and Transformation of Deoxynivalenol. Ph.D. Thesis, University of Guelph, Guelph, ON, Canada, 2007.

80. Carere, J.; Hassan, Y.I.; Lepp, D.; Zhou, T. The enzymatic detoxification of the mycotoxin deoxynivalenol: Identification of DepA from the DON epimerization pathway. Microb. Biotechnol. 2018, 11, 1106-1111. [CrossRef]

81. Carere, J.; Hassan, Y.I.; Lepp, D.; Zhou, T. The Identification of DepB: An Enzyme Responsible for the Final Detoxification Step in the Deoxynivalenol Epimerization Pathway in Devosia mutans 17-2-E-8. Front. Microbiol. 2018, 9, 1573. [CrossRef]

82. Sato, I.; Ito, M.; Ishizaka, M.; Ikunaga, Y.; Sato, Y.; Yoshida, S.; Koitabashi, M.; Tsushima, S. Thirteen novel deoxynivalenoldegrading bacteria are classified within two genera with distinct degradation mechanisms. FEMS Microbiol. Lett. 2012, 327, 110-117. [CrossRef] [PubMed]

83. He, W.-J.; Shi, M.-M.; Yang, P.; Huang, T.; Zhao, Y.; Wu, A.-B.; Dong, W.-B.; Li, H.-P.; Zhang, J.-B.; Liao, Y.-C. A quinone-dependent dehydrogenase and two NADPH-dependent aldo/keto reductases detoxify deoxynivalenol in wheat via epimerization in a Devosia strain. Food Chem. 2020, 321, 126703. [CrossRef] [PubMed]

84. Gao, X.; Mu, P.; Wen, J.; Sun, Y.; Chen, Q.; Deng, Y. Detoxification of trichothecene mycotoxins by a novel bacterium, Eggerthella sp. DII-9. Food Chem. Toxicol. 2018, 112, 310-319. [CrossRef] [PubMed]

85. Qu, R.; Jiang, C.; Wu, W.; Pang, B.; Lei, S.; Lian, Z.; Shao, D.; Jin, M.; Shi, J. Conversion of DON to 3- epi -DON in vitro and toxicity reduction of DON in vivo by Lactobacillus rhamnosus. Food Funct. 2019, 10, 2785-2796. [CrossRef]

86. Wang, Y.; Wang, G.; Dai, Y.; Wang, Y.; Lee, Y.-W.; Shi, J.; Xu, J. Biodegradation of Deoxynivalenol by a Novel Microbial Consortium. Front. Microbiol. 2020, 10, 2964. [CrossRef]

87. Zhang, H.; Zhang, H.; Qin, X.; Wang, X.; Wang, Y.; Bin, Y.; Xie, X.; Zheng, F.; Luo, H. Biodegradation of Deoxynivalenol by Nocardioides sp. ZHH-013: 3-keto-Deoxynivalenol and 3-epi-Deoxynivalenol as Intermediate Products. Front. Microbiol. $2021,12$. [CrossRef]

88. Wang, Y.; Zhang, H.H.; Zhao, C.; Han, Y.T.; Liu, Y.C.; Zhang, X.L. Isolation and characterization of a novel deoxynivalenoltransforming strain Paradevosia shaoguanensis DDB001 from wheat field soil. Lett. Appl. Microbiol. 2017, 65, 414-422. [CrossRef]

89. Zhang, J.; Qin, X.; Guo, Y.; Zhang, Q.; Ma, Q.; Ji, C.; Zhao, L. Enzymatic degradation of deoxynivalenol by a novel bacterium, Pelagibacterium halotolerans ANSP101. Food Chem. Toxicol. 2020, 140, 111276. [CrossRef] [PubMed]

90. He, W.-J.; Yuan, Q.-S.; Zhang, Y.-B.; Guo, M.-W.; Gong, A.-D.; Zhang, J.-B.; Wu, A.-B.; Huang, T.; Qu, B.; Li, H.-P.; et al. Aerobic De-Epoxydation of Trichothecene Mycotoxins by a Soil Bacterial Consortium Isolated Using In Situ Soil Enrichment. Toxins 2016, 8, 277. [CrossRef]

91. He, W.-J.; Shi, M.-M.; Yang, P.; Huang, T.; Yuan, Q.-S.; Yi, S.-Y.; Wu, A.-B.; Li, H.-P.; Gao, C.-B.; Zhang, J.-B.; et al. Novel Soil Bacterium Strain Desulfitobacterium sp. PGC-3-9 Detoxifies Trichothecene Mycotoxins in Wheat via De-Epoxidation under Aerobic and Anaerobic Conditions. Toxins 2020, 12, 363. [CrossRef]

92. Zhai, Y.; Zhong, L.; Gao, H.; Lu, Z.; Bie, X.; Zhao, H.; Zhang, C.; Lu, F. Detoxification of Deoxynivalenol by a Mixed Culture of Soil Bacteria With 3-epi-Deoxynivalenol as the Main Intermediate. Front. Microbiol. 2019, 10, 2172. [CrossRef] [PubMed]

93. Islam, R.; Zhou, T.; Christopher Young, J.; Goodwin, P.H.; Peter Pauls, K. Aerobic and anaerobic de-epoxydation of mycotoxin deoxynivalenol by bacteria originating from agricultural soil. World J. Microbiol. Biotechnol. 2012, 28, 7-13. [CrossRef] [PubMed]

94. He, W.-J.; Zhang, L.; Yi, S.-Y.; Tang, X.-L.; Yuan, Q.-S.; Guo, M.-W.; Wu, A.-B.; Qu, B.; Li, H.-P.; Liao, Y.-C. An aldo-keto reductase is responsible for Fusarium toxin-degrading activity in a soil Sphingomonas strain. Sci. Rep. 2017, 7, 9549. [CrossRef]

95. Ito, M.; Sato, I.; Ishizaka, M.; Yoshida, S.; Koitabashi, M.; Yoshida, S.; Tsushima, S. Bacterial Cytochrome P450 System Catabolizing the Fusarium Toxin Deoxynivalenol. Appl. Environ. Microbiol. 2013, 79, 1619-1628. [CrossRef]

96. Gao, X.; Mu, P.; Zhu, X.; Chen, X.; Tang, S.; Wu, Y.; Miao, X.; Wang, X.; Wen, J.; Deng, Y. Dual Function of a Novel Bacterium, Slackia sp. D-G6: Detoxifying Deoxynivalenol and Producing the Natural Estrogen Analogue, Equol. Toxins 2020, $12,85$. [CrossRef]

97. Ahad, R.; Zhou, T.; Lepp, D.; Pauls, K.P. Microbial detoxification of eleven food and feed contaminating trichothecene mycotoxins. BMC Biotechnol. 2017, 17, 30. [CrossRef]

98. Kiessling, K.H.; Pettersson, H.; Sandholm, K.; Olsen, M. Metabolism of aflatoxin, ochratoxin, zearalenone, and three trichothecenes by intact rumen fluid, rumen protozoa, and rumen bacteria. Appl. Environ. Microbiol. 1984, 47, 1070-1073. [CrossRef]

99. Guan, S.; He, J.; Young, J.C.; Zhu, H.; Li, X.-Z.; Ji, C.; Zhou, T. Transformation of trichothecene mycotoxins by microorganisms from fish digesta. Aquaculture 2009, 290, 290-295. [CrossRef]

100. Niderkorn, V.; Morgavi, D.P.; Pujos, E.; Tissandier, A.; Boudra, H. Screening of fermentative bacteria for their ability to bind and biotransform deoxynivalenol, zearalenone and fumonisins in an in vitro simulated corn silage model. Food Addit. Contam. 2007, 24, 406-415. [CrossRef]

101. Hassan, Y.I.; Zhou, T. Addressing the mycotoxin deoxynivalenol contamination with soil-derived bacterial and enzymatic transformations targeting the C3 carbon. World Mycotoxin J. 2018, 11, 101-112. [CrossRef]

102. Yoshizawa, T.; Takeda, H.; Ohi, T. Structure of a novel metabolite from deoxynivalenol, a trichothecene mycotoxin, in animals. Agric. Biol. Chem. 1983, 47, 2133-2135. [CrossRef]

103. Hassan, Y.I.; He, J.W.; Perilla, N.; Tang, K.; Karlovsky, P.; Zhou, T. The enzymatic epimerization of deoxynivalenol by Devosia mutans proceeds through the formation of 3-keto-DON intermediate. Sci. Rep. 2017, 7, 6929. [CrossRef] [PubMed] 
104. Kelly, S.L.; Kelly, D.E. Microbial cytochromes P450: Biodiversity and biotechnology. Where do cytochromes P450 come from, what do they do and what can they do for us? Philos. Trans. R. Soc. B Biol. Sci. 2013, 368, 20120476. [CrossRef] [PubMed]

105. Woese, C.R.; Fox, G.E. Phylogenetic structure of the prokaryotic domain: The primary kingdoms. Proc. Natl. Acad. Sci. USA 1977, 74, 5088-5090. [CrossRef]

106. Sievers, F.; Wilm, A.; Dineen, D.; Gibson, T.J.; Karplus, K.; Li, W.; Lopez, R.; McWilliam, H.; Remmert, M.; Söding, J.; et al. Fast, scalable generation of high-quality protein multiple sequence alignments using Clustal Omega. Mol. Syst. Biol. 2011, 7, 539. [CrossRef]

107. Minh, B.Q.; Schmidt, H.A.; Chernomor, O.; Schrempf, D.; Woodhams, M.D.; von Haeseler, A.; Lanfear, R. IQ-TREE 2: New Models and Efficient Methods for Phylogenetic Inference in the Genomic Era. Mol. Biol. Evol. 2020, 37, 1530-1534. [CrossRef]

108. Kalyaanamoorthy, S.; Minh, B.Q.; Wong, T.K.F.; von Haeseler, A.; Jermiin, L.S. ModelFinder: Fast model selection for accurate phylogenetic estimates. Nat. Methods 2017, 14, 587-589. [CrossRef]

109. Jonczyk, P.; Takenberg, M.; Hartwig, S.; Beutel, S.; Berger, R.G.; Scheper, T. Cultivation of shear stress sensitive microorganisms in disposable bag reactor systems. J. Biotechnol. 2013, 167, 370-376. [CrossRef]

110. Opinião Positiva da EFSA para o Ingrediente Biomin ${ }^{\circledR}$ BBSH 797 de Mycofix ${ }^{\circledR}$ para Todas as Espécies Avícolas. Available online: https://www2.biomin.net/pt/comunicados-a-imprensa/opiniao-positiva-da-efsa-para-o-ingrediente-biominr-bbsh797-de-mycofixr-para-todas-as-especies-avicolas/ (accessed on 23 January 2020).

111. Payros, D.; Alassane-Kpembi, I.; Pierron, A.; Loiseau, N.; Pinton, P.; Oswald, I.P. Toxicology of deoxynivalenol and its acetylated and modified forms. Arch. Toxicol. 2016, 90, 2931-2957. [CrossRef]

112. Kim, D.-H.; Brunt, J.; Austin, B. Microbial diversity of intestinal contents and mucus in rainbow trout (Oncorhynchus mykiss). J. Appl. Microbiol. 2007, 102, 1654-1664. [CrossRef]

113. Saul, D.J.; Williams, L.C.; Reeves, R.A.; Bergquist, P.L. Secondary structure model for an unusual SSU rRNA from the extremely thermophilic bacterium strain AZ3 B.1. Biochim. Biophys. Acta-Gene Struct. Expr. 1994, 1217, 211-213. [CrossRef]

114. Fröhlich, J.; König, H. Rapid Isolation of Single Microbial Cells from Mixed Natural and Laboratory Populations with the Aid of a Micromanipulator. Syst. Appl. Microbiol. 1999, 22, 249-257. [CrossRef]

115. Ahad, R.; Zhou, T.; Lepp, D.; Pauls, K.P. Draft Genome Sequence of Citrobacter freundii Strain A47, Resistant to the Mycotoxin Deoxynivalenol. Genome Announc. 2017, 5, e00019-17. [CrossRef] 